\title{
The impact of HLA-Cw*12:02 on control of HIV-1 infection
}

\author{
M Koyanagi ${ }^{1 *}$, K Honda ${ }^{1}$, T Chikata ${ }^{1}$, T Akahoshi ${ }^{1}$, H Murakoshi ${ }^{1}$, H Gatanaga ${ }^{2}$, S Oka ${ }^{2}$, M Takiguchi ${ }^{1}$ \\ From AIDS Vaccine 2012 \\ Boston, MA, USA. 9-12 September 2012
}

\section{Background}

Previous studies have demonstrated that higher HLA-C expression, which is determined through a single nucleotide polymorphism $35 \mathrm{~kb}$ upstream and the variation within the 3' untranslated region of the HLA-C locus, associate with slow progression of HIV-1-infected disease. Although HLA-C plays important roles in presenting antigens to CTLs or a ligand for inhibitory killer cell Ig-like receptors (KIR), the role of HLA-C-restricted CTL and NK cells in the control of HIV-1 is still unclear. Our recent study of chronically HIV-1 infected Japanese cohort showed that the HLA-B*52:01-Cw*12:02 haplotype was significantly associated with lower viral load. In this study, we investigated whether HLA-Cw*12:02-restricted CTLs or NK cells via KIR have a significant impact on viraemic control.

\section{Methods}

We sequenced Pol, Gag and Nef from 400 chronically HIV-1 clade B-infected treatment-naïve Japanese individuals and then analyzed amino acid polymorphisms associated with HLA-B*52:01-Cw*12:02 haplotype using Fisher's exact test. Next we performed intracellular IFNg staining or IFNg ELISPOT assay to detect CTL responses to the peptides including those polymorphisms.

\section{Results}

We found 9 amino acid polymorphisms significantly associated with HLA-B*52:01- $\mathrm{Cw}^{*}$ 12:02 haplotype $(\mathrm{p}<0.002$ $\mathrm{q}<0.2$ ). By using ICC assay, we identified $2 \mathrm{Cw}^{*} 12: 02$ restricted CTL epitopes and 4 B*52:01-restricted ones. Four $\mathrm{Cw}^{*}$ 12:02-restricted CTL epitopes including previously reported ones were analyzed to investigate the effect of $\mathrm{Cw}^{*}$ 12:02-restricted CTLs on control of HIV-1. No significant correlation between the responses to these

${ }^{1}$ Center for AIDS Research, Kumamoto University, Kumamoto, Japan Full list of author information is available at the end of the article
$\mathrm{Cw}^{*}$ 12:02-restricted epitopes and viral load was found in chronically HIV-1 infected $\mathrm{Cw}^{*} 12: 02$ positive Japanese individuals.

\section{Conclusion}

Those results showed that HLA-Cw*12:02-restrected CTLs have no effect on control of HIV-1 and suggested that HLA-B*52:01-restrected CTLs or Cw*12:02-resticted NK cells control HIV-1 viraemia in Japanese cohort.

\section{Author details}

${ }^{1}$ Center for AIDS Research, Kumamoto University, Kumamoto, Japan. ${ }^{2}$ AIDS Clinical Center, National Center for Global Health and Medicine, Tokyo, Japan.

Published: 13 September 2012

doi:10.1186/1742-4690-9-S2-P257

Cite this article as: Koyanagi et al:: The impact of $\mathrm{HLA}-\mathrm{CW}^{*} 12: 02$ on control of HIV-1 infection. Retrovirology 2012 9(Suppl 2):P257.

Submit your next manuscript to BioMed Central and take full advantage of:

- Convenient online submission

- Thorough peer review

- No space constraints or color figure charges

- Immediate publication on acceptance

- Inclusion in PubMed, CAS, Scopus and Google Scholar

- Research which is freely available for redistribution

\section{(Ciomed Central}

